Article

\title{
Novel Coating to Minimize Corrosion of Glass-Ceramics for Dental Applications
}

\author{
Shu-Min Hsu ${ }^{1, *}$, Fan Ren ${ }^{2}$, Zhiting Chen ${ }^{2}$, Mijin Kim ${ }^{1}$, Chaker Fares ${ }^{2}$, Arthur E. Clark ${ }^{1}$, \\ Dan $\mathrm{Neal}^{3}$ and Josephine F. Esquivel-Upshaw ${ }^{1}$ \\ 1 Department of Restorative Dental Sciences, University of Florida College of Dentistry, \\ Gainesville, FL 32610, USA; mijinkim@ufl.edu (M.K.); BCLARK@dental.ufl.edu (A.E.C.); \\ JESQUIVEL@dental.ufl.edu (J.F.E.-U.) \\ 2 Department of Chemical Engineering, University of Florida, Gainesville, FL 32611, USA; \\ fren@che.ufl.edu (F.R.); zt.chen@ufl.edu (Z.C.); c.fares@ufl.edu (C.F.) \\ 3 Department of Neurosurgery, University of Florida College of Medicine, Gainesville, FL 32610, USA; \\ dneal@ufl.edu \\ * Correspondence: shuminhsu@ufl.edu
}

Received: 27 January 2020; Accepted: 6 March 2020; Published: 8 March 2020

\begin{abstract}
The effect of a novel silicon carbide ( $\mathrm{SiC}$ ) coating on the chemical durability of a fluorapatite glass-ceramic veneer was investigated by examining weight loss and ion release levels. The hypothesis that this novel coating will exhibit significant corrosion resistance was tested. Inductively coupled plasma atomic emission spectrometer (ICP) was used for ion concentration determination and scanning electron microscopy (SEM) for surface morphology analyses. Samples were immersed in $\mathrm{pH} 10$ and $\mathrm{pH} 2$ buffer solutions to represent extreme conditions in the oral cavity. Analyses were done at 15 and 30 days. The SiC coated group demonstrated significant reduction in weight loss across all solutions and time points $(p<0.0001)$. Ion release analyses demonstrated either a marginally lower or a significantly lower release of ions for the SiC-coated disks. SEM analysis reveals planarization of surfaces by the SiC-coated group. The surfaces of coated samples were not as corroded as the non-coated samples, which is indicative of the protective nature of these coatings. In conclusion, $\mathrm{SiC}$ is a novel coating that holds promise for improving the performance of ceramic materials used for dental applications.
\end{abstract}

Keywords: glass-ceramic; coating; corrosion; weight loss; ion release

\section{Introduction}

Glass-ceramics undergo corrosion [1-8]. Clinical studies have confirmed this [9] and in vitro studies have shown that different $\mathrm{pH}$ levels affect the surface of ceramic adversely. $\mathrm{pH} 10$ was demonstrated to be the most corrosive, followed by $\mathrm{pH} 7$ and $\mathrm{pH} 2$ [1]. The mechanism behind the corrosion process is responsible for the differences in severity. A total dissolution of the network former bonds ( $\mathrm{Si}-\mathrm{Si}$ bonds) occurs in the presence of a $\mathrm{pH} 10$ environment, while an ionic exchange reaction occurs in a $\mathrm{pH} 2$ or acidic environment [1]. $\mathrm{pH} 7$ has an equal amount of ionic exchange and total dissolution that occurs. A recent study [10] concluded that in vitro tests for chemical stability of ceramic products could be underestimating the surface degradation of ceramics by performing tests in constant $\mathrm{pH}$ environments only. The oral environment has a dynamic $\mathrm{pH}$ that can vacillate from acidic to basic with the constant introduction of food items differing in $\mathrm{pH}$ levels and the buffering capacity of saliva. For instance, enamel demineralization and ceramic corrosion can be initiated with all kinds of acidic drinks (e.g., Coca-Cola pH 2.45, Red Bull pH 3.17, orange juice pH 3.74, wines pH 3.34-3.68) [11], food (beef $\mathrm{pH}$ 4.1-7.0, lamb pH 5.4-6.7) and fruits (grapefruits $\mathrm{pH}$ 3.0-3.3, oranges $\mathrm{pH}$ 3.0) [12], or basic 
substances pH 8-14 (e.g., spinach, soybeans, and antacids) [1]. Eventually, this constant change in $\mathrm{pH}$ can decrease the fracture strength of glass-ceramics $[13,14]$ and increase surface roughness $[15,16]$. This roughening of the restoration can lead to plaque accumulation and increased wear of the opposing enamel $[17,18]$. Dental restorations should be able to withstand these fluctuations in $\mathrm{pH}$.

Chemical durability of dental materials has been extensively studied because of the importance of this property on the longevity of the restoration. Intrinsic or extrinsic modifications can be used to improve chemical durability. Several studies have demonstrated chemical stability for glass-ceramics can be enhanced by (1) different ratio of compositions; (2) addition of oxides, such as $\mathrm{CaO}, \mathrm{K}_{2} \mathrm{O}$, and $\mathrm{Al}_{2} \mathrm{O}_{3}$; and (3) fluorine and calcium phosphates as part of intrinsic modifications [19-23]. Extrinsic modification can be achieved by producing additional layers on the surface to enhance chemical durability and other physical properties [24-26]. Esquivel-Upshaw et al. showed that glazed material has better chemical resistance than non-glazed material [1]. Topateş et al. discussed the effect of different glaze compositions on chemical durability [25]. Rau et al. reported that the chemical resistance and corrosion rate of magnesium alloy were improved with the application of a glass-ceramic coating [26].

Chemical durability is also important because leached ions during corrosion may not be safe. The literature demonstrated the cytotoxicity of materials in ceramic [27-30]. Elshahawy et al. reported that $\mathrm{Zn}$ had the highest cytotoxicity (60\% cell viability) to fibroblast cells among the ions released from gold alloys and ceramic crowns in patients' saliva, followed by $\mathrm{Cu}>\mathrm{Ag}>\mathrm{Pd}>\mathrm{Al}>\mathrm{Au}>\mathrm{Si}$. The cytotoxicity was not related to the amount of the ion released in this study; Si had the highest released amount, but the least cytotoxicity ( $90 \%$ cell viability). This indicates Si has higher biocompatibility [28]. Another study analyzed the medium where all-ceramic and provisional materials were immersed and found the materials leached to be slightly cytotoxic [30].

Research has shown that silicon carbide $(\mathrm{SiC})$ is a promising ceramic material for biomedical applications [31-33]. This material has superior properties including lightweight, high strength, corrosion resistance, and high temperature resistance [31-41]. SiC has been incorporated with ceramic as ceramic composites $[34,35,42,43]$, where increased strength was demonstrated in ceramic crowns infused with $\mathrm{SiC}$ fibers [42]. Lithium aluminosilicate glass-ceramic reinforced with $\mathrm{SiC}$ fibers and composites of zirconia and $\mathrm{SiC}$ particles both exhibited high strength and toughness [34,35].

In addition, $\mathrm{SiC}$ demonstrated good biocompatibility. Naji and Harmand reported the cytocompatibility of $\mathrm{SiC}$ and amorphous alumina coatings showed that both materials are cytocompatible for human fibroblasts and osteroblasts [44]. Bonaventura et al. explored the biocompatibility of $\mathrm{Si}$ and $\mathrm{SiC}$ coating to neural stem cells. Their findings demonstrated $\mathrm{SiC}$ had higher biocompatibility than $\mathrm{Si}$ [45]. Botsoa et al. showed there was no toxicity after the uptake of $\mathrm{SiC}$ nanoparticles by 3T3-L1 fibroblasts cells for one week [46]. However, the reported results are controversial because the cytotoxicity was also dose-dependent, morphology-dependent, and structure and surface property-dependent $[47,48]$.

The latest research demonstrated that $\mathrm{SiC}$ is a promising coating as dental material, which displayed adjustable color to match the dental shade guide used in clinic and wear resistance [49]. However, the oral environment could be a hostile to dental ceramic materials. For this study, we aim to demonstrate the corrosion resistance of $\mathrm{SiC}$ when used as a coating for glass-ceramic veneers. The objective of this study was to test the hypotheses that SiC-coated fluorapatite glass-ceramic veneers will exhibit significant corrosion resistance under different $\mathrm{pH}$ environments as a function of weight loss and ion release.

\section{Materials and Methods}

\subsection{Specimens Preparation}

Fluorapatite glass-ceramic disks (Ivoclar Vivadent AG, Schaan, Liechtenstein, $12.6 \times 1.3 \pm 0.2 \mathrm{~mm}$ ) were polished through 340 grits, 400 grits. and 600 grits of silicon carbide abrasive paper (Carbimet, Buehler, Lake Bluff, IL, USA) on both sides, cleaned with ethanol under ultrasonic, and rinsed 
thoroughly using deionized water. The composition of the fluorapatite disks is listed in Table 1 from Ivoclar Vivadent (Schaan, Liechtenstein) scientific documentation.

Table 1. The compositions of the fluorapatite disks used in this study [34].

\begin{tabular}{cccccccccccc}
\hline Composition & $\mathrm{SiO}_{2}$ & $\mathrm{Al}_{2} \mathrm{O}_{3}$ & $\mathrm{Na}_{2} \mathbf{O}$ & $\mathrm{K}_{2} \mathbf{O}$ & $\mathbf{C a O}$ & $\mathrm{ZnO}$ & $\mathrm{ZrO}_{2}$ & $\mathbf{P}_{2} \mathrm{O}_{5}$ & $\mathbf{F}$ & $\begin{array}{c}\text { Other } \\
\text { Oxides }\end{array}$ & Pigments \\
\hline $\mathrm{Wt} \%$ & $57.0-62.0$ & $12.0-16.0$ & $7.0-10.0$ & $6.0-8.0$ & $2.0-4.0$ & & $1.5-2.5$ & $1.0-2.0$ & $0.5-1.0$ & $0-6.0$ & $0.2-0.9$ \\
\hline Atomic \% & $58.6-51.6$ & $14.5-15.7$ & $13.9-16.1$ & $7.8-8.5$ & $2.2-3.5$ & & $0.7-1.0$ & $0.4-0.7$ & $1.6-2.6$ & & \\
\hline
\end{tabular}

\subsection{Coating Fabrication}

Silicon dioxide $\left(\mathrm{SiO}_{2}\right)$ and silicon carbide $(\mathrm{SiC})$ dielectric films were applied to ceramic disks. A total thickness of $250 \mathrm{~nm}$ with $20 \mathrm{~nm}$ for $\mathrm{SiO}_{2}$ and $230 \mathrm{~nm}$ for $\mathrm{SiC}$ was observed. The $\mathrm{SiO}_{2} / \mathrm{SiC}_{\text {dielectric }}$ films were deposited using plasma-enhanced chemical vapor deposition (PECVD, PlasmaTherm 790, Saint Petersburg, FL, USA). Prior to deposition of the dielectric film, a series of cleaning procedures were applied to the glass-ceramic disks to remove debris on the surface produced during polishing. Particle remnants can cause locally induced stresses, which can compromise the adhesion of the coating. Cleaning was achieved through ultra-sonication for $1 \mathrm{~min}$ in a solution with a 0.2 ratio between hydrochloric acid and de-ionized water. The solution was changed to just de-ionized water and sonicated for $2 \mathrm{~min}$. The cleaning procedure was repeated three times.

The configuration of PECVD was a parallel plate with a showerhead and a load lock. The substrate holder temperature was maintained at $300{ }^{\circ} \mathrm{C}$, where the $\mathrm{SiO}_{2} / \mathrm{SiC}$ films were deposited on the glass-ceramic disks. Further, $2 \%$ silane balanced $\left(\mathrm{SiH}_{4}\right)$ in argon and nitrous oxide $\left(\mathrm{N}_{2} \mathrm{O}\right)$ were the precursors for $\mathrm{SiO}_{2}$ film. The silane and methane were the precursors for $\mathrm{SiC}$ film. The deposition conditions were well calibrated. The deposition rate was $330 \AA / \mathrm{min}$ for $\mathrm{SiO}_{2}$ and $170 \AA / \mathrm{min}$ for $\mathrm{SiC}$. The $\mathrm{SiO}_{2}$ was deposited on a glass-ceramic disk and then the $\mathrm{SiC}$ was deposited next on $\mathrm{SiO}_{2} /$ glass-ceramic.

\subsection{Experimental Design}

The two groups in this study are (i) non-coated fluorapatite glass-ceramic disks as reference, and (ii) $\mathrm{SiO}_{2} / \mathrm{SiC}$ coated fluorapatite glass-ceramic disks ( $\mathrm{SiC}$-disks). All the disks were dried in an oven (Isotemp Vacuum Oven Model 285A, Fisher Scientific) at a temperature of $100-105^{\circ} \mathrm{C}$ for $24 \mathrm{~h}$ and cooled in a vacuum desiccator prior to weighing. The weight measurement was performed before and after the corrosion experiment with an accuracy of $0.1 \mathrm{mg}$ (AS60/220.R2 Analytical balance, RADWAG). The disks were constantly immersed in (i) $15 \mathrm{~mL}$ of $\mathrm{pH} 10$ (potassium carbonate-potassium borate-potassium hydroxide buffer, SB116-500, Fisher Chemical, Pittsburgh, PA, USA) and (ii) $15 \mathrm{~mL}$ of $\mathrm{pH} 2$ buffer solutions (glycine buffer solution, Santa Cruz Biotechnology, Inc., Dallas, TX, USA) in polyethylene centrifuge tubes (Thermo Scientific Nalgene Oak Ridge High-Speed Centriguge Tubes, Thermo Fisher Scientific, Waltham, MA, USA) for 15 and 30 days. Three disks were used for each condition. The tubes were placed in a rotating shaking water bath (water bath shaking TSBS40, Techne, Vernon Hills, IL, USA) at 50 oscillations per minute at $80^{\circ} \mathrm{C}$. After corrosion, the level of ions released into the solution was obtained by inductively coupled plasma atomic emission spectrometer (ICP, 3200RL, PerkinElmer, Waltham, MA, USA). Ions examined were $\mathrm{Si}, \mathrm{Ca}, \mathrm{Zn}$, and Al.

Statistical analysis was performed using Mann-Whitney $\mathrm{U}$ test to determine significant differences in weight loss and ion release between the groups.

\subsection{Characterizations}

The surface morphology of reference and SiC-disks was examined by scanning electron microscopy (SEM). The disks were sputter coated with platinum and then analyzed using field-emission SEM (Nova Nano 430, FEI, Hillsboro, OR, USA). The images were obtained at $5 \mathrm{kV}$. 
The surface composition of reference disks was investigated by X-ray photoelectron spectroscopy instrument (ULVAC-PHI XPS, ULVAC-PHI, Kanagawa, Japan) with Al monochromatised K $\alpha$ radiation from a $50 \mathrm{~W}$ X-ray source.

\section{Results}

\subsection{Weight Loss}

Comparison of weight loss between coated and non-coated dental glass-ceramic disks for different $\mathrm{pH}$ solutions and time periods is shown in Figure 1. Weight loss was significantly more for the non-coated groups across all solutions and time points $(p<0.0001)$.

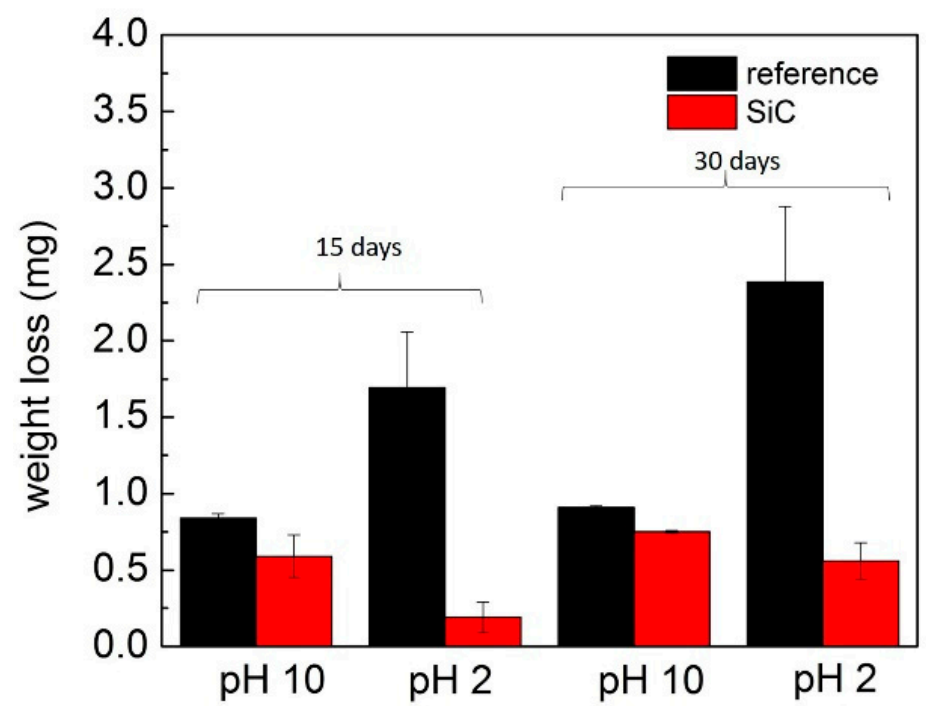

Figure 1. The weight loss of non-coated (ref) and silicon carbide ( $\mathrm{SiC}$ )-coated disks constantly immersed in $\mathrm{pH} 10$ and $\mathrm{pH} 2$ for 15 and 30 days.

Comparison of weight loss in solutions between coated and non-coated dental glass-ceramic demonstrates there was significantly less weight loss among SiC coated disks both in $\mathrm{pH} 10(p=0.005)$ and $\mathrm{pH} 2(p=0.010)$ compared with their controls.

The $\mathrm{SiC}$ coating displayed a protective effect for $\mathrm{pH} 2$ and $\mathrm{pH} 10$ between non-coated and SiC-disks. The weight loss in $\mathrm{pH} 2$ was nine times less at 15 days $(p=0.004)$ and four times less for 30 days $(p=0.008)$ for the coated disks compared with the non-coated disks. The weight loss of coated disks was slightly less in $\mathrm{pH} 10$ than the non-coated disks after 30 days' immersion $(p=0.076)$.

\subsection{ICP Analysis}

The level of released ions from non-coated and SiC-coated disks in the solutions was analyzed after corrosion. The levels of ions released from non-coated disks are shown in Figure 2. The highest released ion was $\mathrm{Si}^{4+}$ in both buffer solutions, as this ion was the network former in the glass-ceramic and the main component in the $\mathrm{SiC}$ coating (Figure 2a). The overall $\mathrm{Si}^{4+}$ released across solutions and timepoints was significantly lower for SiC-coated disks $(p=0.014)$. The level of $\mathrm{Si}^{4+}$ released at $\mathrm{pH} 2$ was marginally lower $(p=0.01)$ in SiC-coated disks than the non-coated disks, but was not significant at $\mathrm{pH} 10(p=0.699)$. 

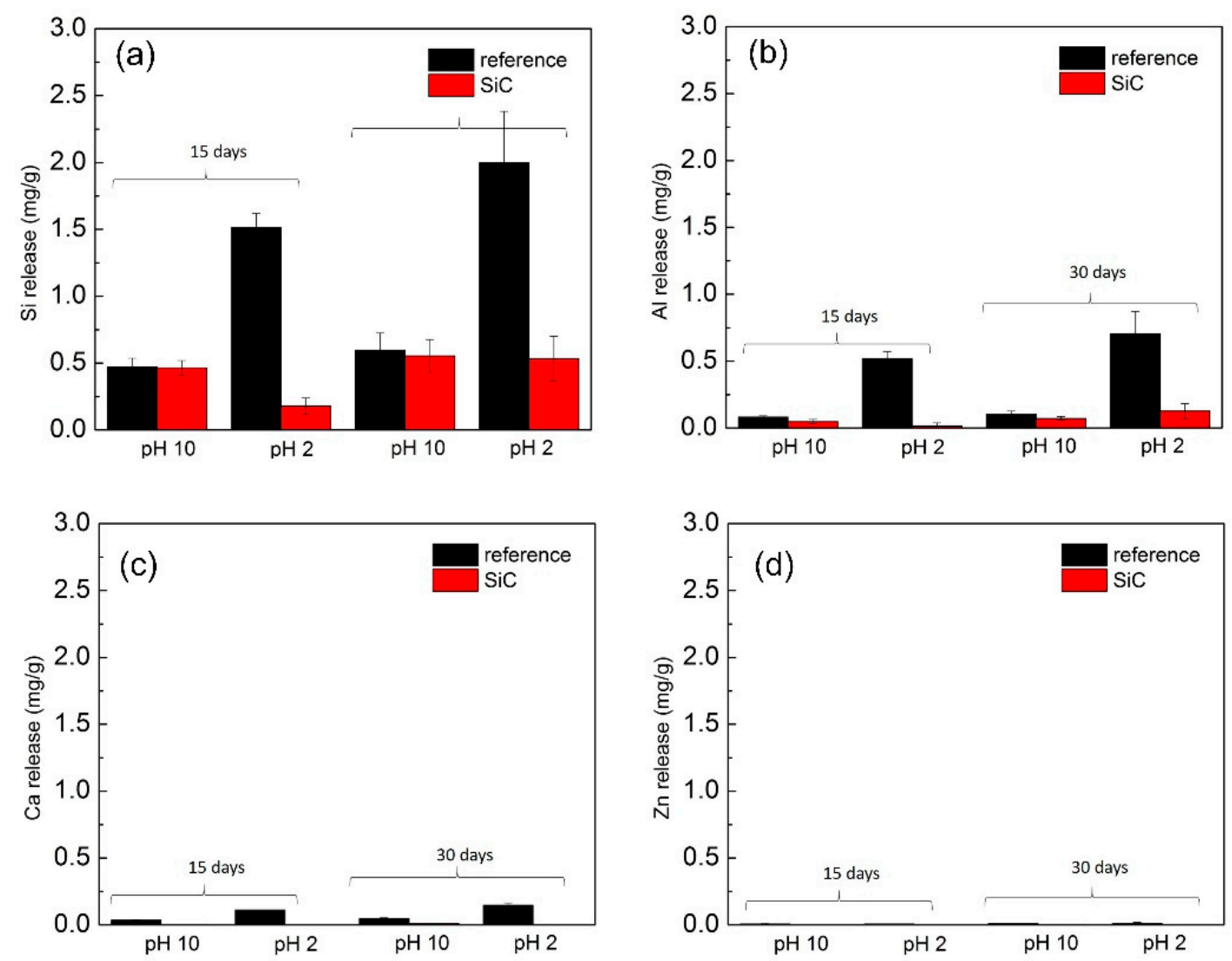

Figure 2. Ion release of (a) $\mathrm{Si}^{4+}$, (b) $\mathrm{Al}^{3+}$, (c) $\mathrm{Ca}^{2+}$, and (d) $\mathrm{Zn}^{2+}$ for $\mathrm{SiC}$-coated and non-coated disks at $\mathrm{pH} 10$ and $\mathrm{pH} 2$ for 15 and 30 days.

For the other ions, which are network modifiers, the overall release level was $\mathrm{Al}^{3+}>\mathrm{Ca}^{2+}>\mathrm{Zn}^{2+}$. These levels of ions released in the non-coated disks were compared with the SiC-coated disks in Figure $2 \mathrm{~b}, \mathrm{~d}$. The $\mathrm{SiC}$ coating demonstrated a significantly resistive effect against corrosion in both environments for all ions. The overall release of $A l^{3+}$ for both solution types and across all time points was significantly less for SiC-coated disks $(p=0.003)$ (Figure $2 b)$. When grouped by solution, $A l^{3+}$ ion release was significantly less with the $\mathrm{SiC}$ coating in $\mathrm{pH} 10(p=0.016)$ as well as in $\mathrm{pH} 2(p=0.010)$. When grouped by time point, there was less $A l^{3+}$ released at 15 days $(p=0.004)$ for SiC-disks than 30 days $(p=0.083) . \mathrm{Ca}^{2+}$ was released significantly less with SiC-coated disks across all solutions and time points $(p<0.001)$ (Figure $2 \mathrm{c}$ ). SiC-coated disks had significantly reduced $\mathrm{Ca}^{2+}$ release in $\mathrm{pH} 10$, and there was no detectable release of this ion for $\mathrm{pH}$ 2. Grouped by timepoint, $\mathrm{Ca}^{2+}$ was released significantly less in SiC disks at $15(p=0.007)$ and $30(p=0.008)$ days. $\mathrm{Zn}^{2+}$ was released significantly less in SiC-disks across all $\mathrm{pH}$ environments and time points $(p<0.0001)$ (Figure 2d). As with $\mathrm{Ca}^{2+}$, there was almost no release of $\mathrm{Zn}^{2+}$ ions from SiC disks in $\mathrm{pH} 2(p=0.006)$ and significantly less release at $\mathrm{pH} 10(p=0.002)$.

\subsection{XPS Analysis}

The surface composition of the disks was analyzed using XPS (Figure 3 and Table 2). After immersion in $\mathrm{pH} 10$, the spectrum had a slightly higher atomic ratio of $\mathrm{Si}, \mathrm{Al}, \mathrm{Na}$, and $\mathrm{K}$, whereas the $\mathrm{Al}, \mathrm{Na}, \mathrm{K}$, and $\mathrm{Ca}$ were not detected on the corroded surface in $\mathrm{pH} 2$ (Table 2). This is in agreement with the results of ions release (Figure 2). The ions were exchanged from the reacted surface with ions in the solution. 


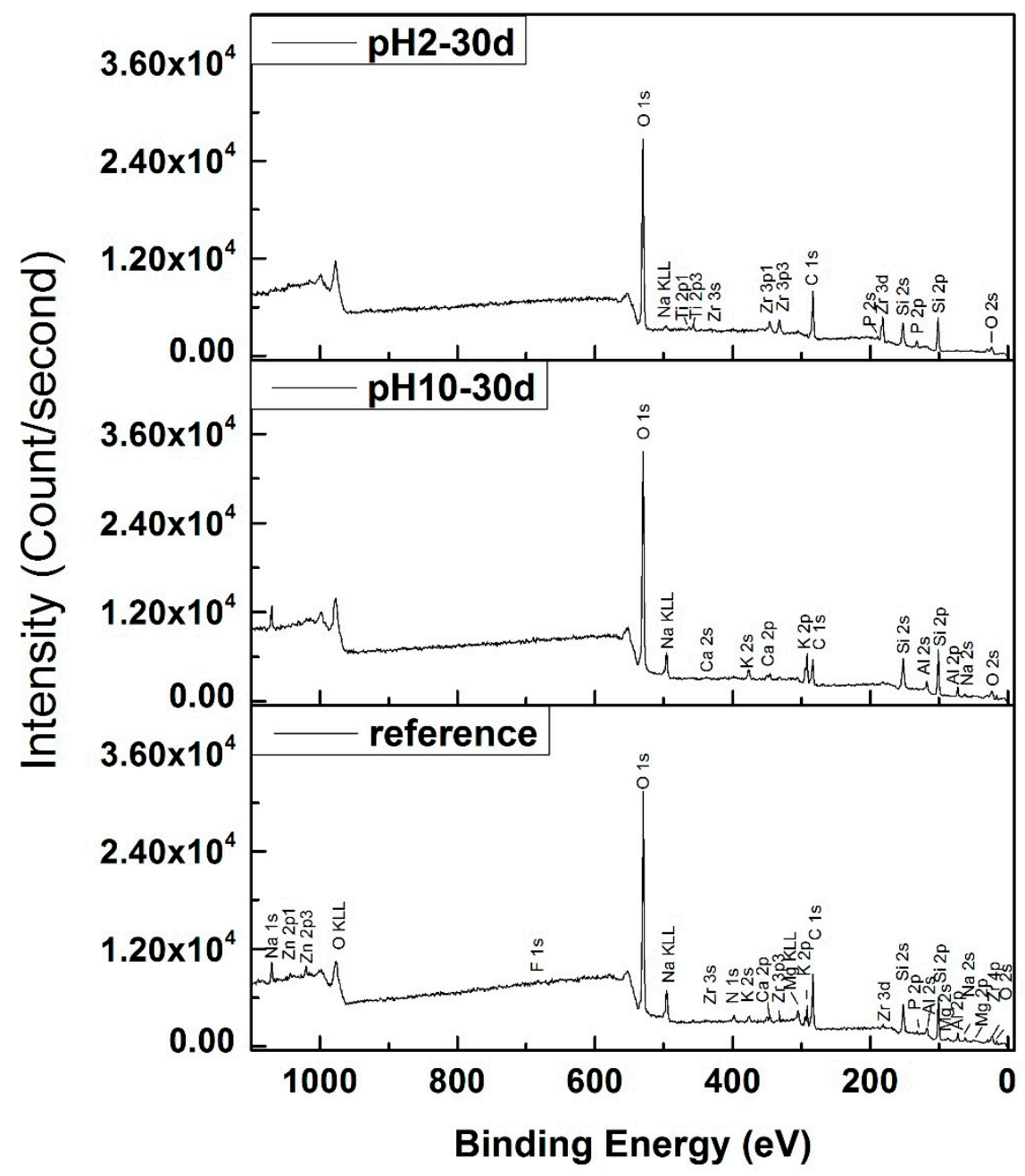

Figure 3. The X-ray photoelectron spectroscopy (XPS) survey for reference, corroded disks in pH 10 and $\mathrm{pH} 2$ after 30 days.

Table 2. The composition of reference, corroded pH 10 disks, and corroded pH 2 disks after 30 days.

\begin{tabular}{|c|c|c|c|c|c|c|c|c|c|c|c|c|}
\hline $\begin{array}{c}\text { Atomic } \\
\text { Ratio }\end{array}$ & $\mathrm{Si}$ & Al & $\mathrm{Na}$ & $\mathbf{K}$ & $\mathrm{Ca}$ & Mg & $\mathrm{Zn}$ & $\mathrm{Zr}$ & $\mathbf{N}$ & $\mathbf{P}$ & $\mathbf{F}$ & $\mathrm{Ti}$ \\
\hline ref & 53.7 & 11.5 & 7.6 & 5.9 & 3.5 & 3.3 & 1.3 & 0.6 & 9.9 & 1.3 & 1.4 & \\
\hline OpH10 & 59.8 & 15.8 & 9.5 & 12.0 & 2.9 & & & & & & & \\
\hline $\mathrm{NpH} 2$ & 76.9 & & 1.1 & & & & & 9.9 & & 8.8 & & 3.3 \\
\hline
\end{tabular}

\subsection{SEM Analysis}

The SiC coating was able to planarize the surface of glass-ceramic disks and seal surface porosities that were produced during fabrication. The images of SiC-disks before and after 30 days' immersion are shown in Figure 4. The morphology of SiC-disks showed mostly good coverage and adhesion in pH 10 and $\mathrm{pH}$ 2. Surface roughness was evident in $\mathrm{pH} 10$ and $\mathrm{pH} 2$ non-coated disks after immersion, but was not too apparent on the SiC-disks immersed for the same time period. These findings are in agreement with weight loss and ICP data (Figures 1 and 2). This demonstrated that SiC coating is an effective approach to improve the chemical stability of glass-ceramic materials by minimizing corrosion. 

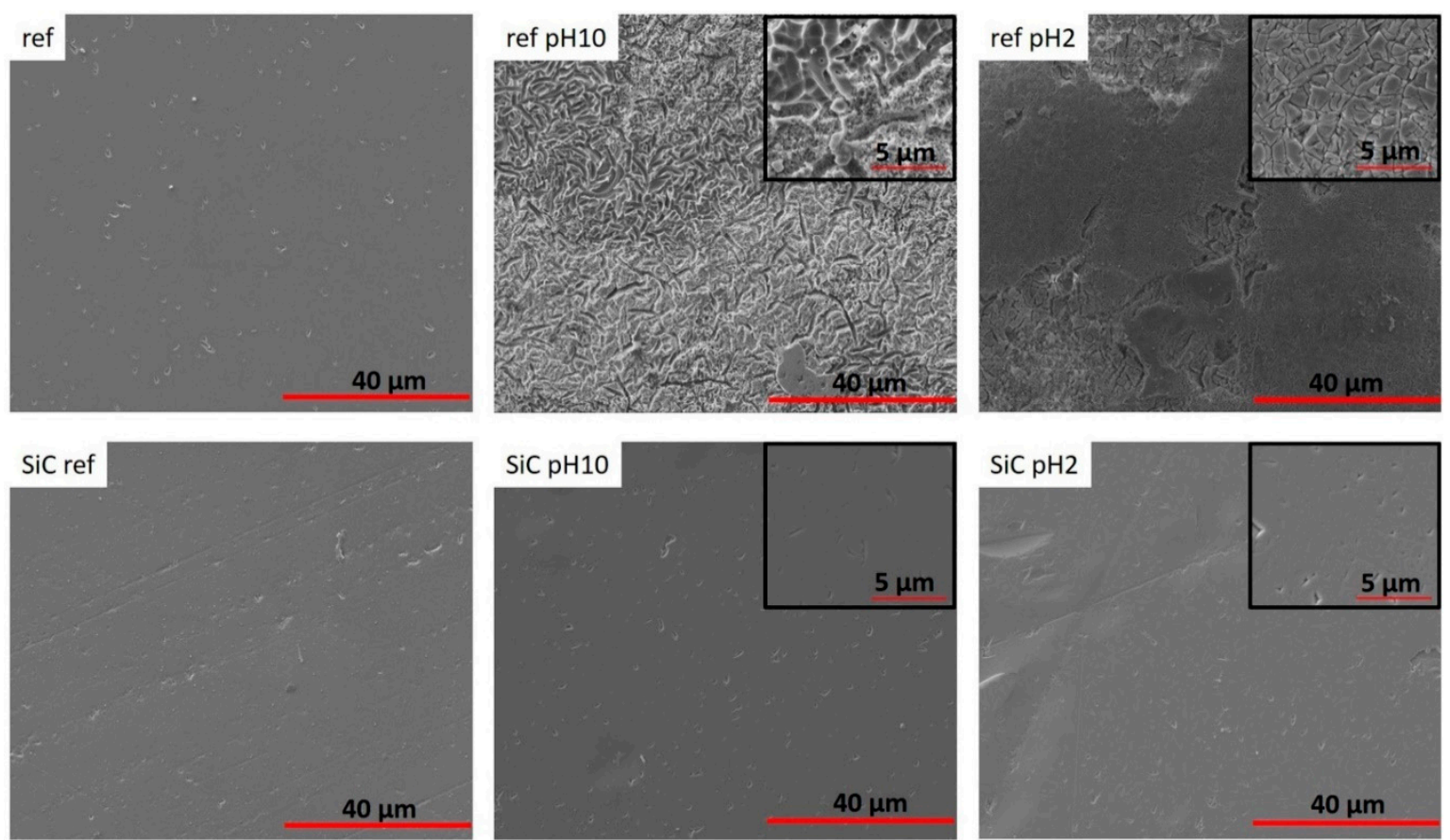

Figure 4. The images of reference (non-coating) and SiC-disks at 0 days (baseline) and 30 days after corrosion in $\mathrm{pH} 10$ and $\mathrm{pH}$ 2. Scale bar: $40 \mu \mathrm{m}$ and $5 \mu \mathrm{m}$.

\section{Discussion}

The purpose of this study was to investigate whether this novel SiC coating will improve and exhibit significant corrosion resistance. Previous studies concluded that ceramic materials undergo a corrosion process when exposed to different $\mathrm{pH}$ environments. Corrosion produces surface degradation, which leads to roughening of the surfaces of ceramic crowns and wear of opposing enamel $[1,10,50]$. This in turn leads to plaque accumulation, secondary caries, and periodontal inflammation. Corrosion can also lead to discoloration of the restoration and a decrease in fracture strength of the glass-ceramic $[13,14,51]$. The results of this study demonstrated that $\mathrm{SiC}$ coating is an effective approach to improve the chemical stability of glass-ceramic materials by minimizing corrosion and maintaining a smoother surface (Figures 1, 2 and 4). The weight loss was significantly less for SiC-coated disks for all $\mathrm{pH}$ environments and time conditions. The application of the $\mathrm{SiC}$ coating on glass-ceramic can minimize these clinical sequelae from occurring.

Ceramic corrosion can occur through either ionic exchange of surface ions where network modifiers in the ceramic are leached and exchanged with protons or hydronium with those in solution, total dissolution of the glass network, or a combination of both. Previous studies demonstrated that $\mathrm{pH} 2$ promotes ion exchange, $\mathrm{pH} 10$ induces total dissolution with release of the network formers, and $\mathrm{pH} 7$ is a combination of both processes $[1,10]$. During ion exchange, when alkaline ions are released into the solution, a silicon-rich surface can be formed on the surface, which can minimize the exchange process. The trend for weight loss in this study demonstrates a higher loss in $\mathrm{pH} 2$ than $\mathrm{pH} 10$, which is in contrast with results from another study [1]. One explanation could be that a new layer can also form in basic solutions, with $\mathrm{Ca}^{2+}$ ions being dissolved on the surface [52]. This is evidenced by the presence of Ca peaks in the disks immersed in $\mathrm{pH} 10$ solution, but not in $\mathrm{pH} 2$ (Figure 3 and Table 2). The $\mathrm{SiO}_{4}^{-}$attaches to $\mathrm{Ca}^{2+}$, and this limits the ion diffusion in and out of the glass-ceramic. Another possible explanation is that the composition of the material used in this study was different in that the glass-ceramic used in this study had more $\mathrm{Al}_{2} \mathrm{O}_{3}$ (Table 3) [53,54], which is typically used to improve chemical stability [22], as the alumina compound is known to have a small ionization constant in basic solution [55]. When $A l^{3+}$ ions are released into the solution during network dissolution, there is a possible formation of soluble $\left[\mathrm{Al}(\mathrm{OH})_{6}\right]^{3-}, \mathrm{AlO}_{2}{ }^{-}$in the solution [56], or $\mathrm{Al}^{3+}$ precipitates could form 
on the surface to further inhibit the dissolution process. This was also confirmed by ICP analysis, where there was a smaller amount of $\mathrm{Ca}^{2+}$ and $\mathrm{Al}^{3+}$ released into solution from disks immersed in $\mathrm{pH}$ 10 compared with those immersed in $\mathrm{pH}$ 2. The XPS corroborates this by demonstrating $\mathrm{Ca}$ and $\mathrm{Al}$ peaks in $\mathrm{pH} 10$ disks, but not in $\mathrm{pH} 2$.

Table 3. Compositions of the disks from Ivoclar Vivadent scientific documentation for this study and another study $[53,54]$.

\begin{tabular}{ccccccccccccc}
\hline Composition(wt.\%) & $\mathrm{SiO}_{2}$ & $\mathrm{Al}_{2} \mathrm{O}_{3}$ & $\mathrm{Na}_{2} \mathrm{O}$ & $\mathrm{K}_{2} \mathrm{O}$ & $\mathrm{CaO}$ & $\mathrm{ZnO}$ & $\mathrm{ZrO}_{2}$ & $\mathrm{P}_{2} \mathrm{O}_{5}$ & $\mathrm{~F}$ & $\mathrm{Li}_{2} \mathrm{O}$ & $\begin{array}{c}\text { Other } \\
\text { Oxides }\end{array}$ & Pigments \\
\hline This study & $57.0-62.0$ & $12.0-16.0$ & $7.0-10.0$ & $6.0-8.0$ & $2.0-4.0$ & & $1.5-2.5$ & $1.0-2.0$ & $0.5-1.0$ & & $0-6.0$ & $0.2-0.9$ \\
\hline $\begin{array}{c}\text { Esquivel-Upshaw } \\
\text { et al. 2013 }\end{array}$ & $60.0-72.0$ & $2.0-8.0$ & & $10.0-23.0$ & $1.0-10.5$ & $8.5-20.0$ & & $0.5-6.0$ & $0.1-1.0$ & $1.0-5.0$ & $5.0-10.0$ & $0.0-0.3$ \\
\hline
\end{tabular}

The $\mathrm{SiC}$ coating demonstrated a more protective effect on $\mathrm{pH} 2$ by a greater reduction in weight loss between coated disks and non-coated disks compared with disks immersed in $\mathrm{pH} 10$. This can be explained by the corrosion behavior of $\mathrm{SiC}$. The reaction of $\mathrm{SiC}$ has been studied in aqueous solution through the electro-chemical method [56], where $\mathrm{SiC}$ produces a passivating layer of $\mathrm{SiO}_{2}$ in acidic conditions. In contrast, the $\mathrm{SiC}$ dissolves into $\mathrm{SiO}_{3}^{2-}$ in an alkaline solution. Therefore, the corrosion of $\mathrm{SiC}$ was much weaker in $\mathrm{pH} 2$ than in $\mathrm{pH} 10$, as confirmed by the results from this study.

The $\mathrm{SiC}$ also demonstrated a resistive effect for the release of all ions, with the exception of $\mathrm{Si}^{4+}$, which had only marginally lower release. All ions demonstrated either marginally significant or significant effects of $\mathrm{SiC}$ at decreasing the release of ions into solution. A possible explanation for this is that the main component of the $\mathrm{SiC}$ films is $\mathrm{Si}^{4+}$, and as such, would be the first line of defense for the chemical attack from the buffer solutions. The weight loss data prove that not much else was leached from the disks coated with the SiC film. For the network modifiers, there was no detectable release of $\mathrm{Ca}^{2+}$ or $\mathrm{Zn}^{2+}$ at $\mathrm{pH}$ 2. $\mathrm{Al}^{3+}$ in SiC-coated disks demonstrated a significant reduction in release overall, but this reduction was more apparent for $\mathrm{pH} 2$ than $\mathrm{pH} 10$. As mentioned previously, $A l^{3+}$ has a small ionization constant and an inhibition layer of $A l^{3+}$ precipitates could have formed on the surface.

One limitation of this study is that a constant immersion experiment was conducted to test the durability of this coating against different $\mathrm{pH}$ levels. This is not a true simulation of oral conditions because the oral environment has constantly changing $\mathrm{pH}$ resulting from different foods and the buffering capacity of saliva. However, the International Standards Organization standard for Dental Ceramic (ISO 6872) still employs constant immersion testing at $\mathrm{pH} 2.4$ to test the chemical durability of ceramics [57].

A new testing methodology was previously introduced to determine the effect of changes in $\mathrm{pH}$ environment to simulate fluctuations intraorally resulting from dietary preferences [10]. This methodology demonstrated that chemical degradation is possibly being underestimated with current in vitro testing using constant immersion. This study determined how well SiC coatings can withstand extreme $\mathrm{pH}$ challenges in constant immersion. Testing SiC coatings in $\mathrm{pH}$ cycling conditions as well as the material's fracture strength and abrasion resistance will be the next step in the continuum of developing novel coatings for predictable ceramic restorations.

\section{Conclusions}

In conclusion, a new and novel $\mathrm{SiC}$ coating can withstand the extreme $\mathrm{pH}$ conditions and improve the longevity of the restoration. This study demonstrated a significant protective effect on the chemical solubility of a glass ceramic veneer under different $\mathrm{pH}$ environments, as evidenced by decreased weight loss and ion release in solution. Ceramic composition played a role in the progression of the dissolution process. In addition, $\mathrm{SiC}$ coating provided the smoother surface after corrosion, which could minimize the plaque accumulation, secondary caries, and periodontal inflammation from occurring. This novel coating could be the next step in improving the longevity of ceramic restorations by increasing chemical resistance and minimizing fracture. Further studies of novel $\mathrm{SiC}$ coatings for dental applications are 
warranted to determine the corrosion resistance in $\mathrm{pH}$ cycling conditions, fracture resistance, and wear compatibility with enamel as in clinical relevance.

Author Contributions: Conceptualization, F.R., J.F.E.-U., and A.E.C.; Methodology, F.R., A.E.C., and J.F.E.-U.; Investigation: S.-M.H., Z.C., and M.K.; Data analysis: S.-M.H., F.R., C.F., A.E.C., D.N., and J.F.E.-U.; Writing-Orginal Draft Preparation, S.-M.H.; Writing-Review and Editing, S.-M.H., F.R., and J.F.E.-U. All authors have read and agreed to the published version of the manuscript.

Funding: This research was funded by NIH-NIDCR Grant R01 DE025001.

Acknowledgments: Ceramic materials were supplied by Ivoclar Vivadent. SEM-EDAX was performed at the Nanoscale Research Facility of the University of Florida.

Conflicts of Interest: The authors declare no conflict of interest.

\section{References}

1. Esquivel-Upshaw, J.F.; Dieng, F.Y.; Clark, A.E.; Neal, D.; Anusavice, K.J. Surface Degradation of Dental Ceramics as a Function of Environmental pH. J. Dent. Res. 2013, 92, 467-471. [CrossRef] [PubMed]

2. Kukiattrakoon, B.; Junpoom, P.; Hengtrakool, C. Vicker's microhardness and energy dispersive x-ray analysis of fluorapatite-leucite and fluorapatite ceramics cyclically immersed in acidic agents. J. Oral. Sci. 2009, 51, 443-450. [CrossRef] [PubMed]

3. Kukiattrakoon, B.; Hengtrakool, C.; Kedjarune-Leggat, U. Degradability of fluorapatite-leucite ceramics in naturally acidic agents. Dent. Mater. J. 2010, 29, 502-511. [CrossRef]

4. Ccahuana, V.Z.S.; ÖZcan, M.; Mesquita, A.M.M.; Nishioka, R.S.; Kimpara, E.T.; Bottino, M.A. Surface degradation of glass ceramics after exposure to acidulated phosphate fluoride. J. Appl. Oral Sci. 2010, 18, 155-165. [CrossRef] [PubMed]

5. Kukiattrakoon, B.; Hengtrakool, C.; Kedjarune-Leggat, U. The effect of acidic agents on surface ion leaching and surface characteristics of dental porcelains. J. Prosthet. Dent. 2010, 103, 148-162. [CrossRef]

6. Milleding, P.; Haraldsson, C.; Karlsson, S. Ion leaching from dental ceramics during static in vitro corrosion testing. J. Biomed. Mater. Res. 2002, 61, 541-550. [CrossRef] [PubMed]

7. Milleding, P.; Karlsson, S.; Nyborg, L. On the surface elemental composition of non-corroded and corroded dental ceramic materials in vitro. J. Mater. Sci. Mater. Med. 2003, 14, 557-566. [CrossRef] [PubMed]

8. Milleding, P.; Wennerberg, A.; Alaeddin, S.; Karlsson, S.; Simon, E. Surface corrosion of dental ceramics in vitro. Biomaterials 1999, 20, 733-746. [CrossRef]

9. Esquivel-Upshaw, J.F.; Rose, W.F.J.; Barrett, A.A.; Oliveira, E.R.; Yang, M.C.; Clark, A.E.; Anusavice, K.J. Three years in vivo wear: Core-ceramic, veneers, and enamel antagonists. Dent. Mater. J. 2012, 28, 615-621. [CrossRef]

10. Esquivel-Upshaw, J.F.; Ren, F.; Hsu, S.-M.; Dieng, F.Y.; Neal, D.; Clark, A.E. Novel Testing for Corrosion of Glass-Ceramics for Dental Applications. J. Dent. Res. 2018, 97, 296-302. [CrossRef]

11. Lussi, A.; Megert, B.; Peter Shellis, R.; Wang, X. Analysis of the erosive effect of different dietary substances and medications. Br. J. Nutr. 2012, 107, 252-262. [CrossRef] [PubMed]

12. McGlynn, W. The Importance of Food pH in Commercial Canning Operations 2016. pp. 118-1-118-8. Available online: https://extension.okstate.edu/fact-sheets/the-importance-of-food-ph-in-commercialcanning-operations.html (accessed on 7 March 2020).

13. Ajaal, T.T.; Ebdewi, E.A.A. Degradation Effect on the Flexural Strength \& Micro-Hardness of IPS e-max Laminated Ceramics. Int. J. Eng. Innov. 2019, 8, 172-180.

14. Mohsen, C. Corrosion effect on the flexural strength \& micro-hardness of ips e-max ceramics. Open J. Stomatol. 2011, 1, 29-35.

15. Reddy, N.R.; Padmaja, B.I.; Devi, G.; Priya, G.K.; Bindu, G.H.; Babu, N.S. The effect of commonly consumed beverages on colour stability and surface roughness of two metal ceramic materials: An in-vitro study. J. NTR Univ. Health Sci. 2018, 7, 31-38. [CrossRef]

16. Thaworanunta, S.; Sriprasert, N.; Tarawatcharasart, P.; Subtanarat, A.; Cholsiri, C.; Ratanasaovaphak, K.; Thanatawinwongsa, N.; Phrajunpanich, P. Exposure to coffee and bleaching altered surface treated lithium disilicate porcelain color and surface roughness. M. Dent. J. 2019, 39, 267-276. 
17. Teughels, W.; Van Assche, N.; Sliepen, I.; Quirynen, M. Effect of material characteristics and/or surface topography on biofilm development. Clin. Oral Implants Res. 2006, 17, 68-81. [CrossRef]

18. Go, H.; Park, H.; Lee, J.; Seo, H.; Lee, S. Effect of various polishing burs on surface roughness and bacterial adhesion in pediatric zirconia crowns. Dent. Mater. J. 2019, 38, 311-316. [CrossRef]

19. Tulyaganov, D.U.; Agathopoulos, S.; Kansal, I.; Valério, P.; Ribeiro, M.J.; Ferreira, J.M.F. Synthesis and properties of lithium disilicate glass-ceramics in the system $\mathrm{SiO} 2-\mathrm{Al} 2 \mathrm{O} 3-\mathrm{K} 2 \mathrm{O}-\mathrm{Li} 2 \mathrm{O}$. Ceram. Int. 2009, 35, 3013-3019. [CrossRef]

20. Monmaturapoj, N.; Lawita, P.; Thepsuwan, W. Characterisation and Properties of Lithium Disilicate Glass Ceramics in the SiO2-Li2O-K2O-Al2O3 System for Dental Applications. Adv. Mater. Sci. Eng. 2013, 2013, 1-11. [CrossRef]

21. Barrett, J.M.; Clark, D.E.; Hench, L.L. Glass-ceramic dental restoration. U.S. Patent 4,189,325, 19 February 1980.

22. Wu, J.M.; Cannon, W.R.; Panzera, C. Castable glass-ceramic composition useful as dental restorative. U.S. Patent 4,515,634, 7 May 1985.

23. Kasuga, T.; Kimata, T.; Obata, A. Preparation of a Calcium Titanium Phosphate Glass-Ceramic with Improved Chemical Durability. J. Am. Ceram. Soc. 2009, 92, 1709-1712. [CrossRef]

24. Wang, X.; Cai, S.; Liu, T.; Ren, M.; Huang, K.; Zhang, R.; Zhao, H. Fabrication and corrosion resistance of calcium phosphate glass-ceramic coated Mg alloy via a PEG assisted sol-gel method. Ceram. Int. 2014, 40, 3389-3398. [CrossRef]

25. Topateş, G.; Tarhan, B.; Tarhan, M. Chemical durability of zircon containing glass-ceramic glazes. Ceram. Int. 2017, 43, 12333-12337. [CrossRef]

26. Rau, J.V.; Antoniac, I.; Fosca, M.; De Bonis, A.; Blajan, A.I.; Cotrut, C.; Graziani, V.; Curcio, M.; Cricenti, A.; Niculescu, M.; et al. Glass-ceramic coated Mg-Ca alloys for biomedical implant applications. Mater. Sci. Eng. C 2016, 64, 362-369. [CrossRef] [PubMed]

27. Elshahawy, W. Cytotoxicity of Dental Ceramics Used for Manufacturing Dental Fixed Prosthesis: A Systematic Review. M. J. Dent. 2016, 1, 1-10.

28. Elshahawy, W.; Shohieb, F.; Yehia, H.; Etman, W.; Watanabe, I.; Kramer, P. Cytotoxic effect of elements released clinically from gold and CAD-CAM fabricated ceramic crowns. Tanta Dent. J. 2014, 11, 189-193. [CrossRef]

29. Elshahawy, W.M.; Watanabe, I.; Kramer, P. In vitro cytotoxicity evaluation of elemental ions released from different prosthodontic materials. Dent. Mater. 2009, 25, 1551-1555. [CrossRef]

30. Atay, A.; Gürdal, I.; Bozok Çetıntas, V.; Üşümez, A.; Cal, E. Effects of New Generation All-Ceramic and Provisional Materials on Fibroblast Cells. J. Prosthodont. 2019, 28, e383-e394. [CrossRef]

31. González, P.; Serra, J.; Liste, S.; Chiussi, S.; León, B.; Pérez-Amor, M.; Martínez-Fernández, J.; de Arellano-López, A.R.; Varela-Feria, F.M. New biomorphic SiC ceramics coated with bioactive glass for biomedical applications. Biomaterials 2003, 24, 4827-4832. [CrossRef]

32. Filardo, G.; Kon, E.; Tampieri, A.; Cabezas-Rodríguez, R.; Di Martino, A.; Fini, M.; Giavaresi, G.; Lelli, M.; Martínez-Fernández, J.; Martini, L.; et al. New Bio-Ceramization Processes Applied to Vegetable Hierarchical Structures for Bone Regeneration: An Experimental Model in Sheep. Tissue Eng. Part A 2014, 20, 763-773.

33. Gryshkov, O.; Klyui, N.I.; Temchenko, V.P.; Kyselov, V.S.; Chatterjee, A.; Belyaev, A.E.; Lauterboeck, L.; Iarmolenko, D.; Glasmacher, B. Porous biomorphic silicon carbide ceramics coated with hydroxyapatite as prospective materials for bone implants. Mater. Sci. Eng. C 2016, 68, 143-152. [CrossRef]

34. Brennan, J.J.; Prewo, K.M. Silicon carbide fibre reinforced glass-ceramic matrix composites exhibiting high strength and toughness. J. Mater. Sci. 1982, 17, 2371-2383. [CrossRef]

35. Mahmud, N.N.; Vajpai, S.K.; Ameyama, K. Fabrication of Yttria Stabilized Zirconia-Silicon Carbide Composites with High Strength and High Toughness by Spark Plasma Sintering of Mechanically Milled Powders. Mater. Trans. 2014, 55, 1827-1833. [CrossRef]

36. Hirayama, H.; Kawakubo, T.; Goto, A.; Kaneko, T. Corrosion Behavior of Silicon Carbide in $290{ }^{\circ} \mathrm{C}$ Water. J. Am. Ceram. Soc. 1989, 72, 2049-2053. [CrossRef]

37. Barringer, E.; Faiztompkins, Z.; Feinroth, H.; Allen, T.; Lance, M.; Meyer, H.; Walker, L.; Lara-Curzio, E. Corrosion of CVD Silicon Carbide in $500{ }^{\circ} \mathrm{C}$ Supercritical Water. J. Am. Ceram. Soc. 2007, 90, 315-318. [CrossRef]

38. Li, K.Z.; Lan, F.T.; Li, H.J.; Shen, X.T.; He, Y.G. Oxidation protection of carbon/carbon composites with $\mathrm{SiC}$ /indialite coating for intermediate temperatures. J. Eur. Ceram. Soc. 2009, 29, 1803-1807. 
39. Kim, D.; Lee, H.G.; Park, J.Y.; Park, J.Y.; Kim, W.J. Effect of dissolved hydrogen on the corrosion behavior of chemically vapor deposited $\mathrm{SiC}$ in a simulated pressurized water reactor environment. Corros. Sci. 2015, 98, 304-309. [CrossRef]

40. Martínez-Fernández, J.; Valera-Feria, F.M.; Singh, M. High Temperature Compressive Mechanical Behavior of Biomorphic Silicon Carbide Ceramics. Scr. Mater. 2000, 43, 813-818. [CrossRef]

41. Ramírez-Rico, J.; Singh, M.; Zhu, D.; Martínez-Fernández, J. High-temperature thermal conductivity of biomorphic SiC/Si ceramics. J. Mater. Sci. 2017, 52, 10038-10046. [CrossRef]

42. De'rand, T. Reinforcement of porcelain crowns with silicon carbide fibers. J. Prosthet. Dent. 1980, 43, 40-41. [CrossRef]

43. Niihara, K. New design concept of structural ceramics-Ceramic nanocomposites. J. Ceram. Soc. Jpn. 1991, 99, 974-982. [CrossRef]

44. Naji, A.; Harmand, M.-F. Cytocompatibility of two coating materials, amorphous alumina and silicon carbide, using human differentiated cell cultures. Biomaterials 1991, 12, 690-694. [CrossRef]

45. Bonaventura, G.; Iemmolo, R.; La Cognata, V.; Zimbone, M.; La Via, F.; Fragalà, M.E.; Barcellona, M.L.; Pellitteri, R.; Cavallaro, S. Biocompatibility between Silicon or Silicon Carbide surface and Neural Stem Cells. Sci. Rep. 2019, 9, 11540. [CrossRef] [PubMed]

46. Botsoa, J.; Lysenko, V.; Géloën, A.; Marty, O.; Bluet, J.M.; Guillot, G. Application of 3C-SiC quantum dots for living cell imaging. Appl. Phys. Lett. 2008, 92, 173902. [CrossRef]

47. Chen, F.; Li, G.; Zhao, E.R.; Li, J.; Hableel, G.; Lemaster, J.E.; Bai, Y.; Sen, G.L.; Jokerst, J.V. Cellular toxicity of silicon carbide nanomaterials as a function of morphology. Biomaterials 2018, 179, 60-70. [CrossRef] [PubMed]

48. Mzyk, A.; Major, R.; Lackner, J.M.; Bruckert, F.; Major, B. Cytotoxicity control of SiC nanoparticles introduced into polyelectrolyte multilayer films. RSC Adv. 2014, 4, 31948-31954. [CrossRef]

49. Chen, Z.; Fares, C.; Elhassani, R.; Ren, F.; Kim, M.; Hsu, S.-M.; Clark, A.E.; Esquivel-Upshaw, J.F. Demonstration of $\mathrm{SiO} 2 / \mathrm{SiC}$-based protective coating for dental ceramic prostheses. J. Am. Ceram. Soc. 2019, 102, 6591-6599. [CrossRef]

50. Buciumeanu, M.; Queiroz, J.R.C.; Martinelli, A.E.; Silva, F.S.; Henriques, B. The effect of surface treatment on the friction and wear behavior of dental Y-TZP ceramic against human enamel. Tribol. Int. 2017, 116, 192-198. [CrossRef]

51. Gönülol, N.; Yilmaz, F. The effects of finishing and polishing techniques on surface roughness and color stability of nanocomposites. J. Dent. 2012, 40, e64-e70. [CrossRef]

52. Maraghechi, H.; Rajabipour, F.; Pantano, C.G.; Burgos, W.D. Effect of calcium on dissolution and precipitation reactions of amorphous silica at high alkalinity. Cement Concrete. Res. 2016, 87, 1-13. [CrossRef]

53. IPS e.max Zirpress Scientific Documentation; Ivoclar Vivadent Download Center of Scientific Documentation. Available online: https:/www.ivoclarvivadent.com/en/download-center/scientific-documentations/\#I (accessed on 7 March 2020).

54. Bühler-Zemp, P. IPS Empress Esthetic - Scientific Documentation 2004; Ivoclar Vivadent AG: Schaan, Liechtenstein, 2004.

55. Gayer, K.H.; Thompson, L.C.; Zajicek, O.T. The Solubility of Aluminum hydroxide in acidic and Basic Media at $25^{\circ} \mathrm{C}$. Can. J. Chem. 1958, 36, 1268-1271. [CrossRef]

56. Andrews, A.; Herrmann, M.; Sephton, M.; Machio, C.; Michaelis, A. Electrochemical corrosion of solid and liquid phase sintered silicon carbide in acidic and alkaline environments. J. Eur. Ceram. Soc. 2007, 27, 2127-2135. [CrossRef]

57. International Organization for Standardization No. 6872. Dentistry-Ceramic Materials; International Organization for Standardization: Geneva, Switzerland, 2015.

(C) 2020 by the authors. Licensee MDPI, Basel, Switzerland. This article is an open access article distributed under the terms and conditions of the Creative Commons Attribution (CC BY) license (http://creativecommons.org/licenses/by/4.0/). 